\title{
The Paradox of Docket Control: Empowering Judges, Frustrating Refugees
}

\author{
DAGMAR SOENNECKEN
}

This article focuses on the gradual expansion of docket control mechanisms in refugee (or asylum) law proceedings in Germany. It shows that granting judges more and more control over their asylum dockets was a central policy tool repeatedly employed by German politicians over the decades in the hope that it would stem the flow of refugees into the courts and ultimately make it easier (and faster) to deport failed claimants. Politicians were much more willing to limit access to asylum appeals than to appeals in general administrative law, illustrating how the pressure to come up with solutions for the flood of asylum applications overcame established norms for maintaining equal access to the courts for all claimants. Surprisingly, the Constitutional Court remained largely unaffected by these efforts except for a paradigm shift that occurred with the amendment of the constitutional asylum provision in 1993.

\section{INTRODUCTION}

Scholars studying the worldwide expansion of judicial power assume that it is largely a top-down, elite-driven process in which politicians shift power and control to the judiciary through the constitutionalization of rights for their own self-interested purposes (Hirschl 2004). Judges then take up the baton and, in resolving the cases before them, inevitably make public policy through their jurisprudence (Feeley and Rubin 1998). But without sufficient and organized support from below, mobilizing rights inside and outside courts will remain a hollow hope (Rosenberg 2008; Epp 1998). Not only that, judges can only shape policy if they possess sufficient control over their agenda (or docket). "Although a court's attitudinal composition likely influences its agenda," writes Epp, "that influence appears to be conditioned by the extent of discretionary control that judges have over their docket" (Epp 1996, 768). "Docket control," adds Segal, “weeds out legally unambiguous cases," leaving judges "free to vote their sincere preferences" (Segal 1997, 29).

While many higher courts have possessed a large degree of discretionary control since their inception, lower courts have traditionally had much less control over their dockets and must hear a much larger number of cases. However, legislatures in a variety of jurisdictions have been granting lower courts more and more discretionary control over their dockets. Researchers have found that this gradual increase in docket control has resulted in a noticeable agenda shift at this level as well, which suggests that judges at all levels of the

I would like to thank Lisa Conant, Nancy Reichman, and Susan Sterett for their support and encouragement; the anonymous reviewers for their helpful and thorough comments; and, finally, Rob Mauchel and Jesse Morse for their meticulous editorial assistance.

Address correspondence to: Dagmar Soennecken, York University, School of Public Policy \& Administration, 4700 Keele Street, Toronto, Ontario M3J 1P3 Canada. Telephone: 416-736-2100 ext. 33408; E-mail: dsoennec@yorku.ca. 
judicial appeal ladder have readily embraced their newly granted freedoms (Feeley and Rubin 1998; Greene et al. 1998). Indeed, politicians almost seem to be inviting judicial policy making by granting judges more and more control over their dockets, albeit with very different (short-term political) interests in mind. This lends credence to the argument that the growth of judicial power furthers the interests of both legal and political elites.

This article focuses on the gradual expansion of docket control mechanisms in refugee (or asylum) ${ }^{1}$ law proceedings in Germany as a public policy tool, unlike previous research, which has largely focused on the disparate treatment of refugees in the courts (e.g., Miller et al. 2014; Gould, Sheppard, and Wheeldon 2010; Greene and Shaffer 1992). Access to the courts, along with extensive appeal mechanisms and social benefits, has long been considered a pull factor for refugee applications by many reluctant immigration states such as Germany (Joppke 1999). ${ }^{2}$ In fact, one of the leading explanations for the development of early European cooperation on migration and asylum policy views EU policy makers as strategic venue shoppers who circumvent obstacles to their restrictionist policy goals, chief among them judicial rulings, by shifting their efforts $u p$ to the transnational (i.e., EU) level and thus away from domestic courts (Kaunert and Léonard 2012; Guiraudon 2000).

For decades, Germany has been one of the top refugee-receiving countries among advanced industrialized states, mainly due to its unique constitutional right to asylum (Grundgesetz, Basic Law or Constitution GG art. 16(1)), instituted as atonement after WWII, but also due to liberal access to the courts and the sheer volume of applications received. In 1992, Germany restricted this constitutional right following an unprecedented surge in refugee numbers in the aftermath of the fall of the Iron Curtain (Green 2004). Simultaneously, it established a cordon sanitaire around the country by entrenching a range of diversion strategies at the constitutional level that are now common policy across the European Union (Lavenex 2001). While German refugee applications dropped substantially in the years immediately following these changes, Eurostat data for 2014 show that it once again received the most applications in Europe-almost one-third of all applications logged there - even before the extraordinary refugee influx triggered by the war in Syria since the summer of $2015 .^{3}$ Figure 1 shows the number of refugee claims received in Germany from 1960 to 2015.

As Germany struggles to once again process an unprecedented number of claims, methods for speeding up the refugee determination process, including the scaling back of judicial oversight, are back on the agenda. Courts there were already reporting record numbers of appeals and requests for stays of deportation orders in the first quarter of 2015, even before

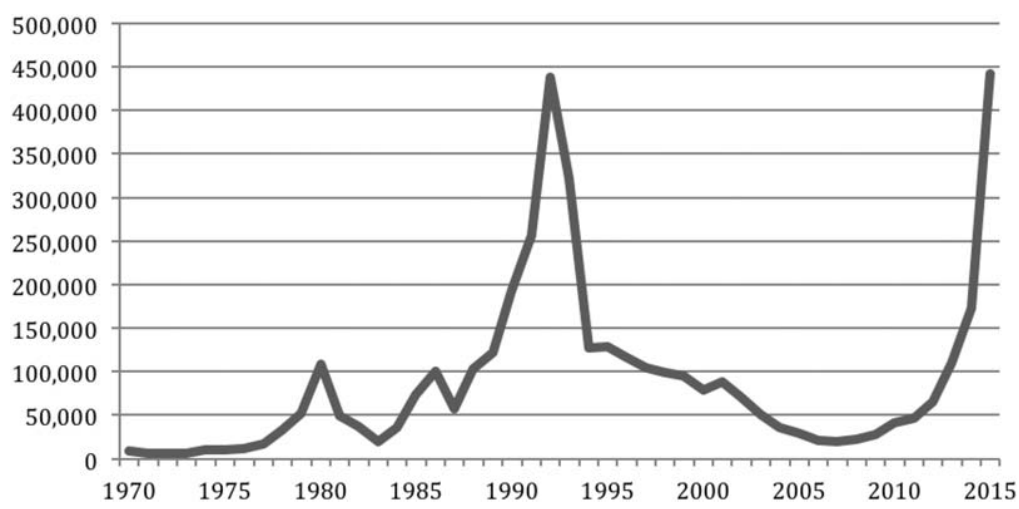

Figure 1. Refugee Claims in Germany, 1960 to 2015.

Source: UNHCR, BAMF. 
the wave of new refugees triggered by the war in Syria started to arrive, underlining the pressure faced by decision makers at all levels. This article places the current situation in a temporal sequence by focusing on the history of events and processes leading up to this moment with the goal of showing how the past affects the present (Pierson 2004).

Looking back shows that granting judges more and more control over their asylum dockets was a central policy tool repeatedly employed by German politicians over the decades in the hope that it would stem the flow of refugees into the courts and ultimately make it easier (and faster) to deport failed claimants. Such policy changes were driven by dramatic spikes in asylum applications each decade, which overwhelmed politicians, bureaucratic decision makers, and the courts. Although the effectiveness of various measures in their ability to accelerate 4 a refugee claimant's journey through the determination process was not systematically studied, and at first their success was limited, German politicians stood by their decision to reduce access to the courts for refugee claimants and even limit it further over subsequent years. The result is a two-tiered system of justice that treats refugee claimants exercising legal rights with suspicion from the start.

This is shown through two strategic comparisons. The first half of the article juxtaposes asylum-specific docket control changes in the administrative courts, which deal with the bulk of Germany's asylum appeals, with those in general administrative law. The comparison shows that, regarding asylum proceedings, docket control changes have been especially pronounced and extensive and have had a profoundly anti-immigrant effect. Politicians were much more willing to limit access to asylum appeals than to appeals in general administrative law, illustrating how the pressure to come up with solutions for the flood of asylum applications overcame established norms for maintaining equal access to the courts for all claimants. Not only that, the limits placed on asylum appeals had a corrosive effect on subsequent changes made to appeals in general administrative law. ${ }^{5}$ The second half of the article examines docket control changes before the Federal Constitutional Court. Here, the absence of any discussion to modify the Court's docket control powers due to its asylum caseload - especially leading up to the dramatic spike in asylum case submissions in the 1990s - is a remarkable contrast to the flurry of changes to asylum law proceedings in the administrative courts. The fact that the government instead chose to amend the constitutional right to asylum underlines the different rules governing constitutional rights games. The conclusion sums up the findings and sketches some of the broader implications for comparative scholars of judicial power.

Process tracing, together with a macrohistorical lens, is used to sketch and compare causal sequences (Pierson 2004). The data and statistics, along with references to interviews, ${ }^{6}$ serve only to contextualize this brief historical look inside the German asylum state and cannot offer a complete picture. Note that although many governments are keenly aware of deficiencies in their previous migration policies and strive to make them evidence based today, some of the gaps in this article's historical data are a reflection of a long-standing disregard for systematically collecting such figures, not to mention commission advisory opinions from policy experts (either inside or outside government). Germany only acknowledged the need for a more technocratic approach to migration policy making around 2000, and to this day Germany still does not consistently draw on knowledge generated by policy experts to inform its decision making (Boswell 2009).

\section{THE GERMAN ADMINISTRATIVE COURTS: THE MAIN ARENA FOR ASYLUM APPEALS} OVERVIEW

In Germany, refugee (or asylum) law is governed by a special version of administrative law, the Asylgesetz (Asylum Code, AsylG; formerly AsylVfG). It continues to follow 
many of the principles of general administrative law outlined in the Verwaltungsgerichtsordnung (Administrative Court Act; VwGO). Yet over the years a number of special docket control rules and procedures were created that grant judges far more control over their asylum dockets than they have over their general caseloads. To illustrate how political imperatives of dealing with rapidly increasing asylum applications overcame shared values within German administrative law regarding access to the courts, docket control reforms pertaining to asylum are contrasted with those in general administrative law in a separate, later section of this article. As already mentioned, asylum-specific docket control changes also had a significant effect on subsequent changes to the general administrative law docket. Before turning to these details, we need to review some general principles of the German administrative law system.

Administrative law has long been shaped by German federalism. Before the (federal) Administrative Court Act was passed in 1960, no unified code of procedures existed. Until that time, the German states operated their own administrative procedure laws, and most restricted access to certain appeals through legislation at the state level, although some differences existed (VwGO para. 124; Sodan and Ziekow 2002). These were only abolished in 1997 when appeal grounds were standardized and a general leave requirement to the Oberverwaltungsgericht/ Verwaltungsgerichtshof (upper administrative court) was introduced. Today all administrative law cases - including asylum cases initially decided by the Federal Office, as well as other cases pertaining to Ausländer (foreigner) law- are first heard by one of fifty-two Verwaltungsgerichte (lower administrative courts or LAC) across the country before proceeding (with leave) to one of sixteen upper administrative courts (or UAC) - one in each state. A few may be granted leave to appeal (i.e., permission from the court to proceed with their appeal) by the Bundesverwaltungsgericht (Federal Administrative Court, FAC) in Leipzig, the highest administrative court in Germany. Access to the FAC has been restricted since the 1920s (VwGO para. 132; Sodan and Ziekow 2002). After these steps, some claimants may still file a constitutional complaint with the Bundesverfassungsgericht (Federal Constitutional Court, Constitutional Court, or FCC), as will be discussed later, or appeal to the European Court for Human Rights (for an overview of the appeals process in general administrative law, see Figure 2). Finally, domestic judges are increasingly making use of the option to refer cases involving Europeanized aspects of administrative law (including asylum questions) to the European Court of Justice for an advisory opinion.

Because GG article 19(4) guarantees everyone access to the courts, no formal docket control procedure exists at the lowest level. This is to ensure the constitutional right to appeal. However, there is an exception to this rule: while lower administrative court judges cannot control their own dockets, they have some say over the next higher court's docket. ${ }^{7}$ In other words, they have some control over whether an appeal (of their own decision) will proceed further. If they rule that an appeal should not be allowed to proceed, the claimant can still ask the upper administrative court for leave to appeal. ${ }^{8}$ This practice of shared docket control also exists between subsequent appeal levels and is not unique to German administrative courts nor to its civil law tradition; the practice is alive and well in Britain and Canada (Ingman 2002; Karlen 1963). ${ }^{9}$ Finally, it is important to note that administrative courts of first and second instance deal with findings of fact and with questions of law (the legal actions are called Klage and Berufung, respectively, ignoring other possible motions). They can also rehear the case in its entirety, reassess existing facts, consider new evidence, call witnesses, and ultimately overturn the previous decision. Since 2001, the upper administrative courts may also seek a ruling from the FAC for some cases (VwGO para. 124b). Appeals before the FAC (called Revision) deal with questions of law only (and are all with leave). Aside from a few exceptions, all appeals, as well 


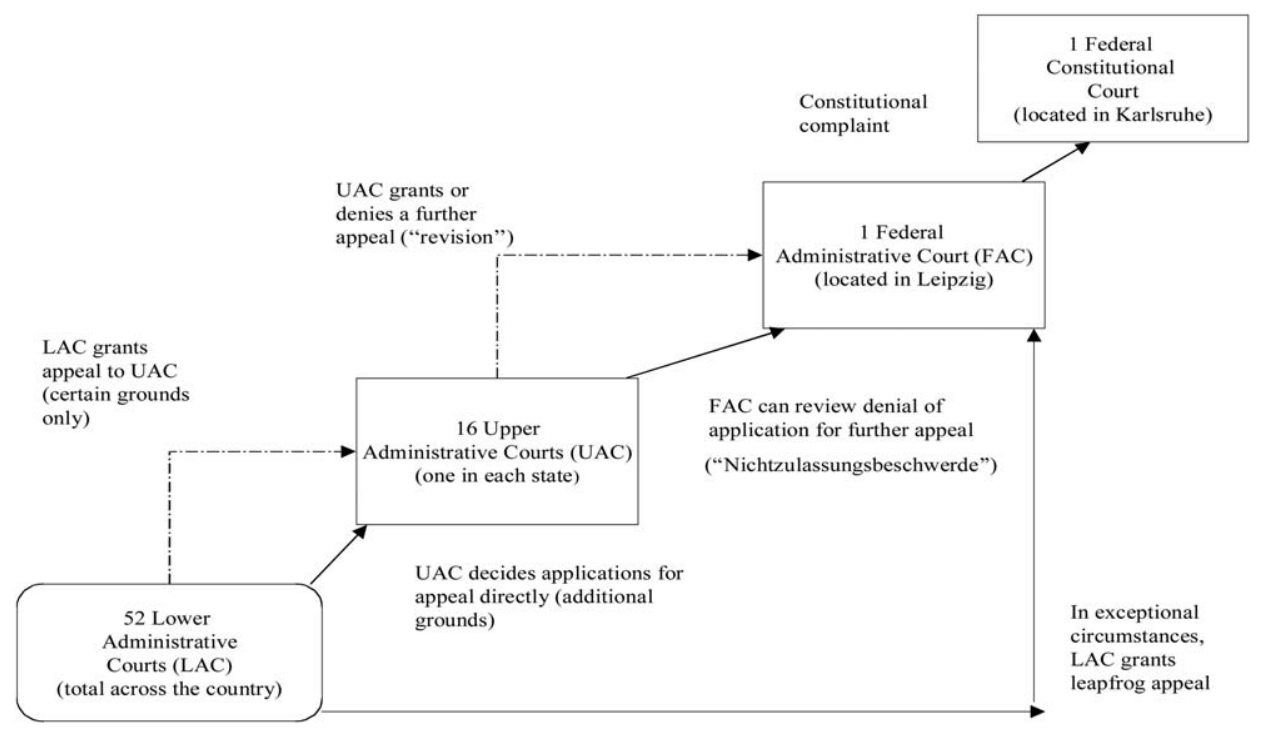

Figure 2. General Appeal Process for Administrative Law Cases.

as all leave to appeal requests, trigger an automatic suspension or stay of the earlier judgment. ${ }^{10}$

\section{REFUGEE CLAIMANTS IN THE ADMINISTRATIVE COURTS}

Germany has taken in some of the largest quantities of refugees in Europe since the end of the Second World War (UNHCR [United Nations Hight Commissioner for Refugees] 2015). ${ }^{11}$ Claims began to first increase substantially after the oil crisis in 1973, which ended the recruitment of foreign workers to Germany under the guest worker regime (Green 2004). Applications jumped by roughly 60 percent, from 5,595 in 1973 to 9,424 in 1974 (for all application numbers, see Figure 1-unless noted otherwise here). However, this was only a mild signal of what was to come in the following decades. Refugee countries of origin began to change as well. Applications from countries other than communist Eastern Europe began to climb rapidly (from single digits to over 30 percent in 1974), mirroring a shift in the world's crisis zones. At the same time, recognition rates began to fall rapidly, from roughly 70 percent in 1971 to around 20 percent in 1976 (BundestagsDrucksache; BT-Drs. 8/448, 5). ${ }^{12}$ By 1978, asylum applications in Germany had risen to 33,436, peaking at a staggering 107,818 in 1980 (Wolken 1988).

Initially, the government introduced visas for a number of the new source countries (e.g., Pakistan in 1976) and made other seemingly minor policy changes. Most were designed to take some of the load off the Federal Office, which had trouble dealing with the rapidly growing asylum applications. One of these changes would prove quite significant later on, namely, the decision to empower border guards and foreigner offices (who were often first points of contact but not formally responsible for reviewing asylum claims) with the ability to turn away refugees whose cases they considered "abusive." Both agencies were also given enhanced deportation powers. The practice of labeling some claims abusive was subsequently expanded to allow whole groups of refugees to be designated as such. Eventually, these cases were renamed manifestly unfounded. Although the Constitutional Court ruled the initial practice of excluding these so-called abusive cases from the refugee determination procedure unconstitutional in 1981 
(BVerfGE 56, 216-44), the manifestly unfounded designation itself survived and would subsequently prove to be perhaps the most powerful determinant of refugee cases inside and outside the courts, as we shall see later on.

In 1978 and 1980, the scope of the reforms increased further. The unceasing growth of applications, combined with the low acceptance rates, fostered the growth of a bogus asylum seeker discourse, which soon found its way into government policy (Münch 1992). The focus now became one of deterring refugees from seeking asylum in Germany. A central strategy was the fast tracking or accelerating (beschleunigen) of refugees through the determination procedure with the end goal of removing them from the country. Not only were existing appeal options considered the primary culprit for the prevailing, drawn-out procedures, but access to the courts was also regarded as a pull factor for potential refugees, since lengthy procedures made it easier for some to eventually stay in the country on humanitarian grounds (Joppke 1999). This attempt to rule failed applicants as deportable more quickly did not in the end result in larger numbers actually being deported (Ellermann 2009). In fact, asylum deporation figures remained fairly constant during the late 1970 s and 1980s. ${ }^{13}$

In response to these acceleration demands, the bureaucratic appeal within the Federal Office was eliminated, as it was considered to only prolong the inevitable (i.e., negative) decision. ${ }^{14}$ Not surprisingly, this change led to a drastic jump in cases before the lower administrative court in Ansbach, where the number of appeals filed more than doubled immediately afterward, which adversely affected processing times. ${ }^{15}$ Given that before the change roughly two-thirds of refugee claimants appealed their initial decision, this was a mighty increase indeed. At the same time, as judicial dockets surged, success rates before the courts plummeted to just below 2 percent (1980), down from a high of 20 percent in 1972 (BT-Drs. 8/2946, 2 and 5; BT-Drs. 8/448).

Next, so-called independent decision makers (from the Ministry of the Interior or $\mathrm{BMI}$ ) replaced the decision-making committees at the Federal Office with the expectation that this would free up personnel and thereby produce efficiencies. However, given their independence from the ministry, a Federal Commissioner for Asylum Affairs was also created to represent the BMI's interests in asylum proceedings in court. He (no woman ever held the office) did so primarily through targeted appeals of initially successful cases, which naturally generated more work for the courts (Zuwanderung gestalten-Integration fördern 2001). ${ }^{16}$

Third, in order to spread the growing costs of housing large numbers of refugees, and as a deterrence measure, refugees were distributed to reception centers all across the country from 1974 onward, instead of to a single location in Bavaria (Boswell 2003). The main criteria for distribution were (and still are) the population of each German state and its tax revenue. This meant that costs and responsibilities for refugees were now shared between all states, which significantly increased the political involvement of the states in asylum policy. Starting in 1978, refugee claims could also be made at a branch of the Federal Office in each region. As a result, administrative courts all across Germany got involved in asylum adjudication from 1980 onward, which unsurprisingly lead to growing discrepancies in case law, thus increasing the caseload before the FAC (Münch 1992).

All in all, these reforms (including hiring more staff) did little to reduce the growing backlog inside and outside the courts; nor could they reduce the processing time for individual cases or stem the steep rise in new refugee cases. Most seasoned observers noted that they merely shifted cases around between the Federal Office and the various courts, thereby creating even more political frustration (ibid.). Part of the problem was that politicians seemed to be so driven by refugee numbers that they searched for quick, shortterm solutions to bring them down, rather than investing in long-term, evidence-based 
policy development or, at a minimum, systematically tracking results (Boswell 2009). As a result, some political actors at both the federal and the state level demanded the introduction of a general leave requirement for asylum cases, while others (largely the representatives of the conservatively governed German states) went so far as to demand that the option to appeal beyond the lower administrative courts be eliminated altogether. However, initially there was no political consensus for such drastic steps (Wolken 1988). The governing coalition between the Social (SPD) and the Free Democrats, which was against such reductions, frequently referred to the constitutional norm of guaranteeing access to the courts and warned of the danger of genuine refugees being turned away if the constitutional asylum protection was further weakened (e.g., BT-Drs. 09/875, 2). Legal observers were also wary of creating special rules for one area of administrative law (Pagenkopf 1982).

Therefore, the 1978 reforms only prevented those applicants whose cases had been designated manifestly unfounded from appealing beyond the lower administrative courtsand, at first, only if a chamber of three judges agreed. In 1979, this affected roughly 39 percent of cases (BT-Drs. 8/4279, 4). ${ }^{17}$ This figure rose to 60 percent by 1981 but dropped to 15 percent in the following years (BT-Drs. 9/875, 25). As an additional twist, such asylum seekers became immediately deportable (i.e., after the negative decision by the Federal Office), and if they did not request a stay of their deportation order within one week, they could be deported before they had the chance to file an appeal.

These changes remained politically controversial for some time, and at first they did not help to reduce the courts' asylum dockets. In fact, many analysts predicted that the number of constitutional complaints would rise as a result, as such a filing entailed an automatic stay of the deportation order. This is indeed what happened (Fullerton 1988; Pagenkopf 1982). The FCC also forced the lower administrative courts to review such cases in sufficient detail by reminding them of their investigative duties under the constitutional asylum provision (BVerfGE 65, 76 and 67, 43).

Moreover, until additional reforms in 1982, the number of manifestly unfounded claimants requesting that the FAC review the decision to deny them any further appeal (Nichtzulassungsbeschwerde) increased dramatically. ${ }^{18}$ These cases were not even statistically recorded prior to 1980 but ballooned from 5,144 in 1980 to 10,003 in 1982, which meant that over 80 percent of the FAC's incoming caseload was suddenly asylum related. Although these requests were much less time intensive than the appeals the court regularly heard, they still created an enormous additional burden for it, as its presiding judge, Horst Sendler, noted in an interview at the time (Von Sternsdorff and Bayer 1982).

Unsurprisingly, the pressure to introduce a general leave requirement in asylum cases grew further until legislation was finally passed in 1982. It maintained the previous limits on appeals beyond the lower administrative courts for manifestly unfounded cases and instituted a leave requirement for all other asylum appeals to the upper administrative courts. Fundamentally, the 1982 legislation focused the upper administrative court's attention on reviewing legal and procedural grounds upon appeal and away from reinvestigating the facts. Moreover, it narrowed the standard of review compared to general administrative law and shortened deadlines for filing an appeal. ${ }^{19}$ An appeal (Berufung) was now only to be accepted if

a. the court considers the issues raised in the case at hand to be of a fundamental nature that had not been resolved yet (Grundsatzrüge);

b. the lower court's decision diverged from the jurisprudence of the upper courts, including the FCC (Divergenzrüge); and

c. a procedural error had been alleged and in fact existed (Verfahrensrüge). ${ }^{20}$ 


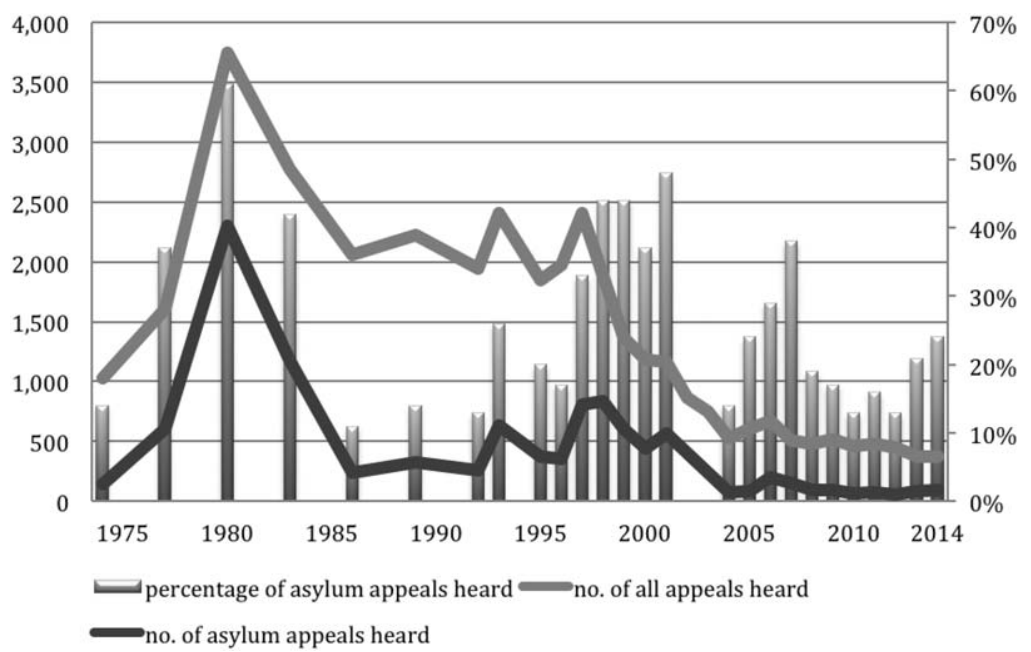

Figure 3. Upper Administrative Court (Bavaria), Appeals Heard.

Source: Statistisches Jahrbuch für Bayern, various years. Data from 2004. https://www.statistik.bayern.de/veroeffentlichungen/advanced_search_result. php?keywords=B6300C (accessed March 21, 2016).

Finally, the 1982 changes also empowered lower administrative courts to assign routine asylum cases to a single judge instead of a panel of three - a measure previously unheard of in administrative law. In practice, because they were so strapped for personnel, many courts even went so far as to assign junior judges more difficult asylum cases (Wolken 1988). ${ }^{21}$ Such single-judge panels officially became the norm for all asylum cases in 1993, though legislation continues to emphasize that especially difficult cases or ones of fundamental importance should be decided by a panel of three.

Available data show that the number of asylum appeals heard, which had peaked in terms of absolute numbers in 1980, plummeted afterward. Their overall share also began to drop dramatically. As Figure 3 shows, while asylum appeals at the upper adminstrative court in Bavaria still made up 42.2 percent of all appeals heard in 1983, the asylum share dropped to 11.4 percent in 1986 and 14.3 percent in $1989 .{ }^{22}$

Although refugee claims in Germany declined between 1981 and 1983, overall processing times were still so lengthy that the drop in asylum appeals heard could not have been caused by the decline in new refugee applications. ${ }^{23}$ In fact, the percentage of new asylum appeals submitted to the upper administrative courts (see Figure 4) remained reasonably constant until the early 1990s (from a low of 19 percent in 1975 to a high of 35 percent in 1983), which underlines that the sharp drop in the number of appeals heard before the UAC from 1982 onward was not caused by a change in refugee claims.

Still, whenever the government heralded the effectiveness of the 1982 reforms, it used the declining numbers of new asylum applications submitted between 1981 and 1983 as a measure of success (e.g., BT-Drs. 10/3346, 2), ${ }^{24}$ although most experts agree that the flow of asylum applications into Germany at the time directly mirrored global political events (Schuster 2003). Moreover, the government's repeated references to the low recognition rates as a justification for the reforms obscured the fact that until 2005 Germany employed a fairly narrow, state-focused definition of political persecution, leaving many claimants from civil war zones in the lurch.

Asylum applications rose again from the mid-1980s on due to escalating violence in Sri Lanka and the Iran-Iraq conflict. In 1988, shortly before the fall of the Berlin Wall, 


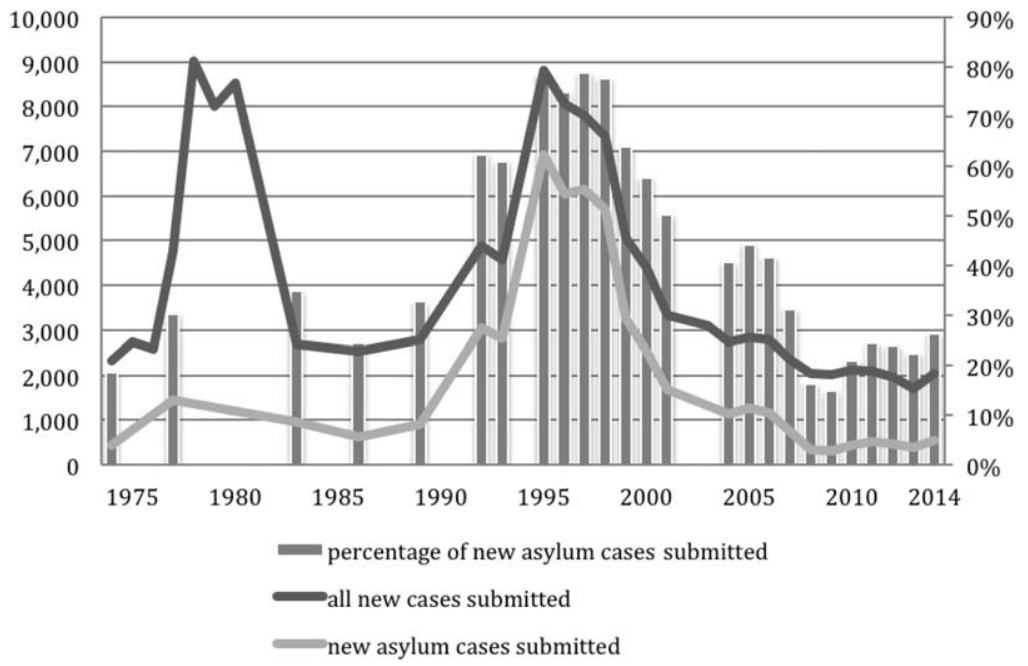

Figure 4. Upper Administrative Court (Bavaria), New Cases Submitted.

Source: Statistisches Jahrbuch für Bayern, various years. Data from 2004. https://www.statistik. bayern.de/veroeffentlichungen/advanced_search_result.php?keywords $=$ B6300C $($ accessed March 21, 2016).

applications submitted in Germany were back over the 100,000 mark, driven by applications from Poland, Turkey, and the former Yugoslavia.

Although a number of additional policy changes were made as a result, asylum applications continued to climb (Münch 1992). In response, the political debate increasingly painted the constitutional right to asylum as a threat to the German state (Schuster 2003). Amending the Constitution now became the central focus of political debate. ${ }^{25}$ But only after the collapse of the Soviet bloc and postreunification, when Germany's asylum applications reached a new and dramatic peak with a staggering 438,191 applications filed in 1992 alone, did the necessary majority required for undertaking such a change emerge. ${ }^{26}$

Growing violence against foreigners and threats by Chancellor Kohl that he would declare a state of emergency (ibid.) eventually persuaded even the SPD, the main opposition party that until then had remained largely opposed to a constitutional change, that an amendment of the asylum guarantee in GG article 16 was necessary. The constitutional amendment was further justified by referring to the growing significance of European harmonization, which, supporters of the amendment argued, Germany could not fully take advantage of due to constitutional constraints (Joppke 1998). The revised GG article 16a allowed the implementation of three measures that became common EU policy afterward: First, refugees coming through a "safe" third country cannot apply for asylum in Germany. Second, those coming from designated safe countries of origin can be more easily returned. Third, those arriving at airports or without documentation can be deemed manifestly unfounded and have their applications fast tracked, limiting their right to appeal and rendering them immediately deportable (Schuster 2003). Although the amendment was subsequently challenged before the Constitutional Court, the Court ruled it constitutional in a trilogy of decisions released in 1996, albeit not unanimously (Bosswick 2000).

The constitutional amendment represented a significant juncture in German refugee policy. Although Germany continued to receive over 100,000 asylum applications annually until the late 1990s (see Figure 1), and the upper administrative court's share of asylum cases actually rose again in the years afterward, ${ }^{27}$ the number of asylum cases heard by the lower administrative courts, which continue to hear the bulk of asylum appeals, 
steadily dropped after $1993 .{ }^{28}$ Subsequently, refugee policy disappeared from political debates (Fullerton 2001). Even when the left-leaning SPD and the Greens won the federal election in 1998, little changed on the asylum front. However, during the war in Kosovo, Germany accepted more refugees from the region than any other country in Europe, the lion's share albeit under a new temporary protection provision (Koser 2000). Moreover, the SPD-Green government eventually pushed through a moderate reform of Germany's citizenship law in 2000 and set up Germany's first commission tasked with studying immigration, headed by a respected member of the Christian Democrats, Rita Süssmuth (Green 2004).

Although the commission's recommendations were considered more liberal than those of the dominant political parties at the time (Schuster 2003), it was not until 2005 that Germany finally undertook another major reform of its migration laws. Nevertheless, the report was still significant in that it advocated a long-term approach to migration policy making beyond an electoral cycle and was "underpinned by far more robust data and analysis" (Boswell 2009, 165). Moreover, in its asylum analysis, the commission rejected any additional changes to the Constitution and also concluded that reducing access to the courts for refugees even further would not only run contrary to emerging trends in harmonizing asylum practices across the European Union but would also fail to produce any further efficiencies. The report pointed out that the recent doubling of processing times for asylum claims was largely due to personnel reductions at the Federal Office and in the administrative court system. It also related differences in processing times between the states and pointed out that most of any reductions were due to the substantial number of manifestly unfounded asylum cases (Zuwanderung gestalten-Integration fördern 2001). ${ }^{29}$ Two key recommendations that would find their way into the 2005 Migration Act (Zuwanderungsgesetz) were the proposals to eliminate the independence of the asylum decision makers at the Federal Office and to abolish the Commissioner for Asylum Affairs.

Until 2010, refugee applications stayed below 30,000 annually, numbers not seen in Germany since the early 1980s. It would take until 2013 for them to climb past the 100,000 mark again. Of the even larger number of asylum claims received in 2014, roughly 30 percent were granted protection during the initial bureaucratic hearing stage (compared to a low of 6.3 percent in 2006), while roughly 75 percent of those rejected were deemed manifestly unfounded - a new high (Bundesamt für Flüchtlinge und Migration 2015). At the same time, 40 percent were appealed to the lower administrative courts. Of those appealed in 2013, 13 percent were reportedly successful (BT-Drs. 18/3850). Despite all the changes discussed, this is still a considerable percentage, underlining that courts will continue to play a significant role in refugee determinations in Germany.

\section{POLICY CHANGES ON DOCKET CONTROL FOR GENERAL ADMINISTRATIVE LAW: FEEDBACK LOOPS}

While administrative court judges were granted more and more control over their asylum dockets each decade, their colleagues adjudicating general administrative law cases, ranging from licensing of radio stations to municipal building codes, were not so lucky. Although these cases were growing rapidly as well in the postwar period (Sodan and Ziekow 2002), there was much resistance to limiting appeals in general administrative law. As a result, docket control reforms proceeded much more hesitantly than in asylum law, and all attempts to introduce a leave requirement for such cases failed until 1996. However, when case pressures grew further and access restrictions were finally introduced, the asylum-specific regulations served as a frequent reference point. 
Early reforms (introduced in 1960 together with the passing of the Administrative Court Act) restricted access to the upper administrative courts for cases deemed less significant. ${ }^{30}$ More importantly, all claimants now needed to be represented by a lawyer on appeal, which was considered a significant change. But with the exception of the latter, these first changes were subject to review after five years, underlining the government's unwillingness to restrict access more permanently at that time. The hope was that the courts' general caseload would eventually lighten again, at which point such restrictions could be lifted. However, the courts' caseload and processing times decreased only temporarily, and a bill with similar restrictions was passed in 1978. These temporary restrictions were further extended throughout the 1980s and eventually made permanent with reforms in 1990 (ibid.). At the same time, voices advocating additional reforms, including the introduction of a general leave requirement, started to grow louder, in particular among the states that, under German federalism, not only implement most federal legislation and have a formal say over such laws in the Bundesrat (Germany's second federal legislative chamber) but can also introduce legislation there.

However, the influential German Lawyers Association publicly rejected the government's 1982 bill containing a general leave requirement for the first time (ibid.), which was representative of the strength of the opposition. Aside from opposing access restrictions, many lawyers also resisted the shift of responsibility from the courts to counsel that instituting such a leave to appeal requirement would entail. Some academics were further concerned that reforms might eliminate fact-related appeals (Seibert 1999). Thus, despite numerous discussions and legislative drafts, subsequent governments remained undecided regarding a grand overhaul of administrative law procedures.

A general leave requirement was not instituted until postreunification woes put additional pressure on the administrative state. In 1994, the government stepped up efforts to create a slimmer and more efficient state apparatus. A government commission tasked with increasing Germany's attractiveness as a place to do business called for extensive procedural reforms to streamline administrative law caseloads. The unceasing pressure on administrative courts resulting from the continuous growth of their asylum dockets, combined with the effectiveness of limiting access to the courts in this area, played an important role in justifying the 1996 changes. Not only was the wording of some asylumspecific rules copied into the legislation, but the official explanation for the new act frequently referred to or distinguished the general provisions from those valid in asylum law, illustrating their corrosive effect on general administrative law procedures (ibid.).

However, reforms in 2001 modified some of these changes. For instance, the government extended the timeline for filing a leave to appeal application for general administrative law cases from two weeks to one month and for filing the detailed reasons from one to two months. It argued that courts had to turn away an unreasonably large number of applications because they were not as thoroughly prepared as they could have been with more time (BT-Drs. 14/6393). Remarkably, the shorter timelines for leave to appeal applications in asylum cases remained unchanged (Seibert 1999), underlining that containing the asylum caseload was still valued more than the preparation of counsel, even under a left-leaning government and during a time of relatively low refugee numbers. ${ }^{31}$

\section{DOCKET CONTROL AND THE GERMAN CONSTITUTIONAL COURT}

The second half of this article is dedicated to an analysis of the docket control changes pertaining to the Federal Constitutional Court. Here, it is the absence of any asylumspecific modifications - short of the constitutional amendment in 1993 - that stands out. 
It serves as a marked contrast to the drastic and frequent changes made to the asylumspecific procedures before the administrative courts discussed in the first half of the article. The fact that the government did not try to modify the Court's regular docket control powers or access criteria, but instead resorted to a constitutional amendment to change the Court's asylum caseload and jurisprudence, underlines the different logics governing constitutional rights proceedings.

It needs to be stated from the outset that the Court's asylum jurisprudence cannot be characterized as aggressively rights expansive on the whole. Nevertheless, the Court certainly issued its share of rulings that clashed with prevailing government opinion, overruled decisions by the (generally more conservative) FAC, and, on the whole, demanded fairly high due process standards. The Court frequently reminded the government of its obligations under the constitutional asylum provision, which was to be interpreted broadly in light of Germany's Nazi past (Joppke 1999). Landmark rulings have limited the state's ability to deport foreigners; affirmed that religious persecution was a valid ground for granting asylum, even if the state was not directly involved; reminded lower adminstrative courts of their investigative duties under the Constitution (Schenk 2002); ordered that claimants who entered the European Union via Greece should not be automatically returned there (under the Dublin regulations), given the poor conditions in Greece; and, finally, declared unconstitutional the limited financial support paid to refugee claimants in 2012 (Kirchhof 2013).

This track record, as a former judge of the FCC wrote in 2013, was considered "too generous" by many politicians around the time of the constitutional amendment. As he explained further, the 1993 amendment was a means of "binding" the Court more closely to the restrictive intent of the policy makers from this point onward (ibid.). Given this background, it is not unreasonable to believe that the 1993 constitutional amendment may have been preceeded by attempts to not only limit access to the administrative courts but to the Constitutional Court as well. Such attempts are not uncommon in a comparative context. ${ }^{32}$ It is therefore important to go back and look (Pierson 2004, 117), even if these paths were not taken. The following section begins with a general overview of how the Court functions before discussing the history of its docket control changes, while the subsequent section scrutinizes the Court's treatment of refugee cases.

\section{OVERVIEW}

Germany's Constitutional Court, founded in 1951, is located in Karlsruhe. It has two Senates with eight justices each. The second Senate has traditionally dealt with asylum cases. Currently, roughly 96 percent of the Court's overall caseload consists of cases in which individuals exercise their right to a constitutional complaint; the remainder involve requests by other courts or governing institutions to evaluate federal-state-level disputes, the constitutionality of a piece of legislation, and so on. ${ }^{33}$ The substantial scope of matters that the Court is allowed to hear makes it more powerful than the US Supreme Court (Kommers 1997). The trust placed in it has consistently far outpaced that of the other branches of government (and indeed, that of other high courts around the world) (Gibson 1998), despite the fact that the Court has certainly issued its fair share of controversial rulings (e.g., Lamprecht 1996).

There are some unique features regarding the internal workings of the FCC worth briefly highlighting here. First, the influence of the Berichterstatter (case reporters) is substantial - that is, judges who become the designated expert in a specific area of law and subsequently author the majority of judgments in that area for their chamber. Second are the presidential secretaries who report to the presiding judge of each Senate. They are 


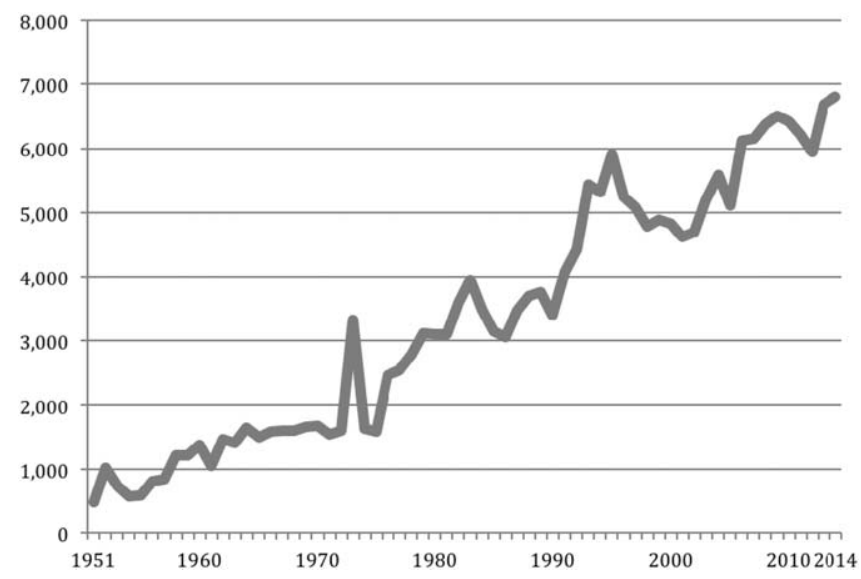

Figure 5. FCC-All Cases Received (Both Senates, All Case Types).

Source: Bundesverfassungsgericht, Annual Statistics. http://www.bundesverfassungsgericht.de (accessed January 10, 2016). Data for earlier years are available on request.

tenured civil servants and fully qualified lawyers who have the authority to close cases deemed hopeless by entering them as such into the Court's general registry. Though complainants can insist on having their file advanced further, observers estimate that up to half do not make it past this stage (Kranenpohl 2010). Third are the justices' law clerks who, unlike their North American counterparts, are typically well beyond law school and stay for three to four years with the Court, hold significant power (they produce drafts of routine decisions, which range from five to thirty pages, sometimes even more), and serve as sounding boards for their judges. ${ }^{34}$ However, the legal specialization of each justice isolates law clerks from one another, rendering ineffective practices such as the certiorari pool, where clerks exchange memorandums to prepare for the judicial conference (which is a common practice among US Supreme Court clerks) (Wieland 2002). Fourth, justices are appointed for a maximum of twelve years and cannot work beyond the retirement age of sixty-eight. Half the justices are nominated and elected by the Bundesrat, the other half by the Bundestag. Care is taken that justices represent the major political parties equally. At least three justices on each Senate must have past judicial experience with one of the specialized federal courts of appeal; most of the others are law professors (Rogowski and Gawron 2002). This appointment procedure is meant to ensure a diversity of political and legal backgrounds.

Since its founding in 1951, the FCC has seen a rapid increase in the total number of cases submitted for review (see Figure 5). ${ }^{35}$ Despite a generally low acceptance rate for constitutional complaints (well under 10 percent of cases over the past decade; see Figure $6),{ }^{36}$ a low success rate by applicants (less than 3 percent on average for 2014, according to the FCC's annual statistics), and numerous docket control reforms (in 1956, 1963, 1970, 1985, and 1993; discussed shortly) that have granted the FCC near absolute power over its docket, the number of cases submitted for review has continued to climb.

Some observers argue that its workload has overwhelmed the Court to the point of disempowering it. Considering its substantial discretion to turn cases away, the Court has also been accused of not using its docket control powers to the fullest (Entlastung des Bundesverfassungsgerichts [Benda Kommission] 1998). Considering that the Court can only hear so many cases a year with a certain staff complement and that a higher number of submissions also increases the potential for cases that deserve to be heard, these accusations do not seem to be grounded in fact. What is more, regardless of how many cases 


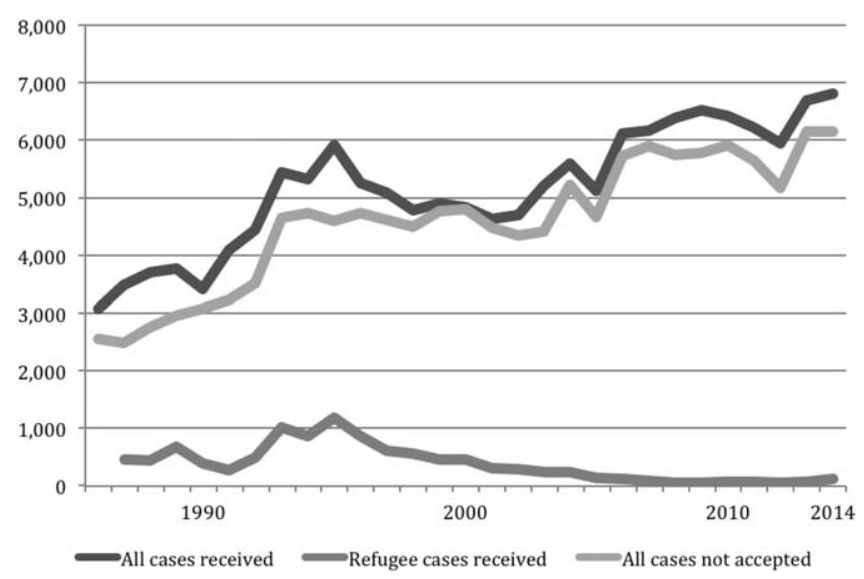

Figure 6. FCC-All Cases Received and Cases Not Accepted vs. Refugee Cases Received. Source: Bundesverfassungsgericht, Annual Statistics. http://www.bundesverfassungsgericht.de (accessed January 10, 2016). Data for earlier years available on request.

were submitted, the fact that the absolute number of cases heard has remained fairly steady over the years (see Figure 6) is an indicator that the Court is actually using its docket control powers to keep the cases heard within a comparable range from year to year. Interestingly, as we shall see shortly, although the legislature has been more than willing to grant the FCC absolute discretion in selecting its cases, for some reason the Court has not been willing to embrace this discretion fully, even when it publicly reported feeling overwhelmed, for example, when the number of asylum cases soared to an all time high in the years before the 1993 constitutional amendment (ibid.), as I will discuss in the last section.

\section{DOCKET CONTROL REFORMS: THE ROAD TO ABSOLUTE POWER?}

The FCC's docket control powers have been amended - indeed, expanded-many times. They are regulated by the Bundesverfassungsgerichtsgesetz (Law Governing the Constitutional Court; BVerfGG). Today, committees of three justices can accept or reject constitutional complaints without offering reasons (though on average, the Court provides reasons in one of four cases). ${ }^{37}$ As legislation sets out only broad criteria, the Court has further used case law to shape the details. While most observers argue that the Court is essentially free to choose its cases, in response the Court has reminded critics that filing a constitutional complaint continues to be a constitutionally protected right in Germany.

The Court enjoyed docket control from the start. Even before changes in 1956, the Court could dispose of "inadmissible or patently unfounded" claims by summary dismissal, which it did in over 96 percent of cases (Singer 1982). ${ }^{38}$ While the government has always been willing to empower the Court, they have also micromanaged who decides. For instance, as a consequence of the 1956 changes, over 95 percent of applications were decided by the newly created committees and no longer by the entire Senate (Benda Kommission 1998; Rivers 1994). Because the government at the time considered the Senate the primary decision-making body of the Court, it curtailed the power of the latter in 1963 only to empower committees (now called chambers) again in 1971, and again further in 1985, due to a substantial caseload increase (Blankenburg 2002). ${ }^{39}$

When the FCC's caseload reached a new high in 1993, with an unprecedented 5,440 applications waiting to be assessed (many of which were asylum cases, as we shall see 
shortly), an amendment to the Court's docket control procedures gave justices even more discretion: broad legal criteria - for instance, fundamental constitutional importance and particularly significant disadvantage - were now left for the Court to interpret. This is the most recent amendment to date. Interestingly, the explanation provided with the government's 1993 bill did not mention its high asylum caseload at all and even invited the Court to consider accepting cases if "the Court perceived there to be deficits in a certain new area of law" or if the Court found that new areas of life posed problems worthy of constitutional consideration (BT-Drs. 12/3628, 7), suggesting that politicans accept the FCC as a legislative body in its own right.

\section{ABSOLUTE POWER VS THE POWER OF THE COURT'S CONSTITUTIONAL MISSION}

What cannot be discerned from a review of the FCC's formal docket control procedures is the fact that, over the years, members of the Court have repeatedly rejected calls by academics, as well as current and former FCC justices, for even more drastic reforms that would abolish the right to file a constitutional complaint entirely. The first call for a shift to discretionary, US-style docket control procedures came from an FCC justice in a 1954 publication. Other FCC justices supported such a move during legislative discussions in 1959. Nothing happened. The president of the Constitutional Court at the time, Justice Zeidler, argued for such a shift again during legislative deliberations in 1985, and another prominent departing justice argued for such changes again in a 1996 speech (Rivers 1994). Finally, the 1998 Benda Commission, staffed with, among others, a number of current and former FCC justices, pushed for a US-style discretionary docket control model one last time - again with no results. The debates have continued since, but no further changes have been introduced into law to date. In 2012, the Court publicly rejected calls for a fifth clerk and mandatory legal representation. Instead, its current president, Andreas Voßkuhle, advocated adding yet another (so called recklessness) fee for abusive claims (so far, to no avail), although legal observers have pointed out that the existing fees, at times, have caused more trouble than they are worth and, historically, have not had much of an effect on the Court's caseload (Burkiczak, Dollinger, and Schorkopf 2015). ${ }^{40}$

Surprisingly, the reason for the lack of movement toward a US-style procedure lay entirely with the Court. After a trial run of eight weeks, during which justices at the time decided cases in parallel according to the current and proposed criteria, they soundly rejected the US model on both practical and philosophical grounds. First, they did not find that the alternate process reduced their caseloads; in fact, they argued that the committee system was more efficient. Second, justices on the bench who were career judges (i.e., not recruits from the universities) were reportedly highly uncomfortable with this step toward total discretion. ${ }^{41}$

An outside observer might well argue that the Court already holds a substantial degree of freedom over its docket. Why does the Court not simply exercise its discretion more aggressively by rejecting even more cases? As the Benda Commission noted, for many members of the Court, introducing US-style discretionary acceptance procedures would require a paradigm shift so profound that it would require a constitutional amendment to accomplish, not only on paper but also in the minds of the FCC justices (Benda Commission 1998). That is how deeply the judges believe in the constitutionally enshrined guarantee to file a constitutional complaint and in their role as the people's court. Clearly, judicial and constitutional culture and norms are more powerful than any desire for even more docket control. 
However, one could argue that this paradigm shift has already occurred in asylum law. When the government amended the Constitution in 1993 to tamp down on the rising violence against foreigners and to bring Germany in line with European refugee policy, it also sent a clear signal to the justices to shift the paradigm according to which they had long assessed asylum applications (Bosswick 2000). Although the right to asylum would remain, it now contained a set of constitutionally entrenched limits. The majority of the Court sanctioned this shift in a trilogy of cases challenging the key provisions of the amendment in 1996 (Frowein and Zimmermann 1996). In it, they granted the government a much larger degree of discretion for evaluating and judging refugee situations (for instance, whether a country can be considered safe) than previously conceivable under the Constitution (BVerfGE 94, 49; 94, 115; 96, 166).

\section{REFUGEE CLAIMANTS BEFORE THE CONSTITUTIONAL COURT}

The year before the FCC's ruling on the constitutional amendment in 1996, an all-time high number of refugee cases were submitted to the Court for consideration. A total of 1,192 applications (see Figure 7), representing 20 percent of all cases brought before the Court that year, were filed. ${ }^{42}$ The new cases that arrived at the Court as part of the socalled airport procedure that was introduced with the constitutional amendment were contributing factors. The airport procedure allowed border police at the airport to refuse refugee claimants entry to the country and/or threaten immediate removal if their case was found to be manifestly unfounded (Benda Kommission 1998). This procedure, with its tight deadlines and limited appeal options, roughed up (aufgemischt) and disrupted (gestört) the Court significantly, as some justices were repeatedly pulled out of meetings to attend to calls from the airport (much like US justices for death penalty cases), as one judge I interviewed recalled. ${ }^{43}$

As Figure 7 shows, since then case submissions have dropped off drastically. In 2008, only fifty of 6,245 constitutional complaints concerned asylum law-a new historic low. The number has remained low until recently, when in 2014 it rose slightly to 119 of 6,606 total complaints.

While the drastic drop in cases filed before the FCC coincides with the aftermath of the 1992 constitutional amendment and the 1996 ruling of the Court confirming its constitutionality, it is not easy to prove that the drop in case submissions was caused by either. It

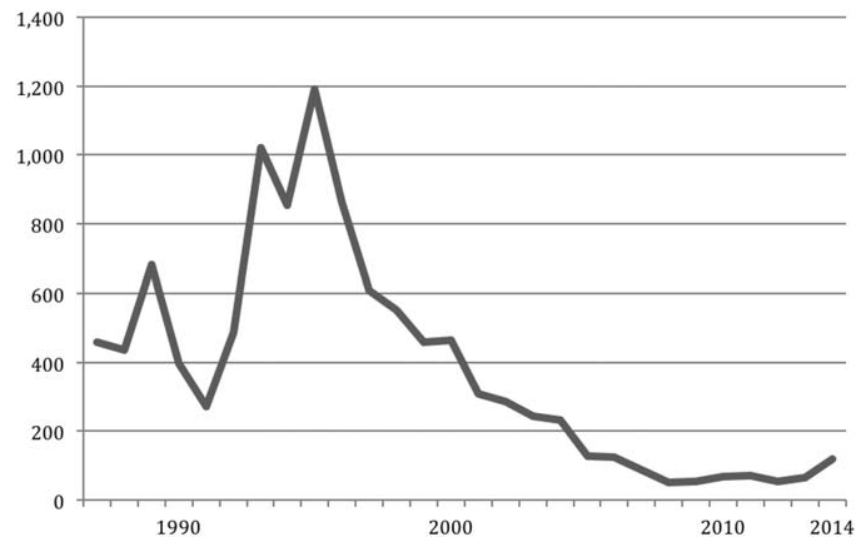

Figure 7. FCC-All Refugee Cases Received.

Source: Bundesverfassungsgericht, Annual Statistics. http://www.bundesverfassungsgericht.de (accessed January 10, 2016; no refugee case data collected prior to 1988). 
is more likely that the lower numbers are an effect of the EU harmonization in this area, which prevented many refugees from reaching Germany and increased applications in neighboring EU countries instead. Refugee flows also shifted to Central Europe in the 1990s, reducing the share of applications received by the old EU-15 countries to 79 percent. At the same time, the number of asylum claims received in other advanced industrialized countries (notably North America and Oceania) increased (UNHCR Population and Geographic Data Section 2001).

What is more interesting for our purposes is that there are at least some indications that refugee cases may have had a higher acceptance rate than other cases and were also more successful prior to the constitutional amendment. This conclusion comes with a significant caveat. It is difficult to verify because of the lack of official data for (1) acceptance rates of constitutional complaint applications and (2) success rates by policy area over time (asylum is the only policy area listed separately under the FCC's success statistics, albeit only since 1991; success here refers to the Court ruling in the applicant's favor). With respect to success rates, a former FCC judge estimated that before the constitutional amendment the success rate was "very high," or about 10 percent. ${ }^{44}$ Observers in the legal community told me that their success rate has dropped off since 1996 (the year in which the Court confirmed the constitutionality of the 1993 amendment), which is confirmed by the Court's official statistics. It lists a total of fifty-seven asylum cases as successful between 1997 and 2014, an average of 3.17 percent - still above the Court's general reported average success rate of 2.3 percent for 2014 (Bundesverfassungsgericht 2014).

With respect to acceptance rates, interviews with two FCC justices, both former asylum law case reporters and therefore specialists in this policy area, suggest that docket control criteria are not considered helpful when it comes to refugees' applications. ${ }^{45}$ According to them, most refugee cases have met the core criteria governing acceptance during their time on the bench: claimants face a particularly significant disadvantage if the Court decides not to hear the case, their decision is necessary for the enforcement of a right, and, finally, the case is of fundamental constitutional importance. Deportation cases - especially decisions involving imminent removal - are considered even more important. This does not mean that all claimants are successful, but it apparently makes it hard for the Court to turn them away.

While the justices I interviewed clearly saw the amendment as a critical turning point, they did not speculate on its particular effects. NGO observers and refugee lawyers I interviewed certainly thought that it initiated a more restrictionist period of acceptance and rulings. Regardless, a lower quantity of rulings does not necessarily imply that a Court's jurisprudence will be more conservative, but the observation made by the refugee lawyers and NGO observers is still interesting and requires further research. More recently, the FCC has certainly made some significant rulings that can be considered rights expansive, such as a ruling that the basic financial support offered to refugees violated the Constitution (BVerfG, 18.07.2012-1 BvL 10/10, 1 BvL 2/11). What is significant for our purposes is that the German government went to such great lengths to achieve such a paradigm change in the first place and that it chose a constitutional amendement instead of ordinary legislation to achieve its goal.

\section{CONCLUSION}

This article took us inside the German asylum state with the goal of placing current dramatic events in a temporal sequence following events and processes of the past to better understand the present. In particular, it has shown that granting administrative court 
judges more control over their asylum dockets was central to the German government's strategy to accelerate the processing of refugee claims over the decades. Surprisingly, the Constitutional Court remained largely unaffected by these efforts, except, of course, for the paradigm shift that occurred with the amendment of the constitutional asylum provision in 1993. The analysis in this article shows that the German government was not merely concerned with improving procedural efficiency. Reducing access to the courts was at the heart of a deterrence strategy that was driven by profoundly anti-immigrant attitudes that painted most refugees as bogus asylum seekers.

Dealing with large numbers (and fluctuations) in refugee applications in a fair and equitable manner remains a formidable public policy challenge for many nations, not just for Germany. Unquestionably, the emotional, social, and economic costs of unnecessarily leaving refugees in legal limbo are high for both the claimants and the receiving countries (Coates and Hayward 2005). Moreover, applying for asylum is a fundamental right protected by international law. Yet designing a procedure that is not only efficient but also affordable (given that even the richest states have limited financial resources) not to mention just, is ultimately up to the receiving states, as the 1951 Geneva Convention does not mandate a particular type of procedure, nor does it set out what rights should be granted to applicants in the process. As a result, there are a wide variety of refugee determination procedures among signatory states, including substantial differences regarding access to the courts. In the European Union, the EU Procedures Directive (2005/85/EC) now mandates that refugee claimants in the European Union receive access to an "effective remedy before a court or tribunal" and be granted a right to consult a legal advisor during their initial (i.e., bureaucratic) hearing. ${ }^{46}$ However, NGO observers continue to criticize the difficulties in actually providing refugee claimants in the European Union with such advice, in particular for those whose claims are subject to tight timelines because they are detained or fast tracked or whose claims were already deemed unfounded (European Council on Refugees and Exiles 2013). These challenges will only become greater as the details of an EU-Turkey become reality.

From a human rights perspective, the trend toward adopting more and more control measures that either exclude individuals from accessing the asylum system from the outset or fast track them one way or the other by cutting off avenues for possible recourse (Kneebone 2009) remains problematic. Research has consistently shown that refugees are more vulnerable and disadvantaged than other individuals throughout the refugee determination process. In the European Union, decisions by domestic courts in various member states, the European Court of Human Rights, and, more recently, the EU's Court of Justice have criticized and, at times, invalidated such government policies (ibid.). Clearly, broader and bolder solutions must be found that also satisfy human rights standards.

At a larger level, the findings of this article show that we need more comparative studies of judicial policy agendas across countries and policy areas. We do not yet know, for instance, how the changes made to Germany's judicial asylum docket over time compare to those in other countries. Certainly, this study has shown that German politicians have been more than willing to grant judges more control over their asylum dockets in order to achieve their own immediate migration control goals. However, although the data show that the asylum caseload of the administrative courts has dropped over the years, given the detailed criteria found in the German asylum procedure code it remains questionable how much room for discretionary decision making administrative court judges actually still have. As one senior upper administrative court judge further reminded me in an interview, the detailed legislative criteria do not allow judges to simply accept (or reject) a case before them soley based on their own judgement - it is up to the refugee's legal representative to make the case. ${ }^{47}$ Moreover, studying docket control changes across all courts 
involved in reviewing asylum decisions has revealed an interesting contrast between the politics involved in restricting access to the Constitutional Court versus the specialized administrative courts. More research into the relationship between higher and lower courts in other policy areas (and other countries) is needed to further evaluate these results.

\section{NOTES}

1. Note that I use the words asylum and refugee interchangeably throughout. The first is more common in European literature, the latter in North America. Unlike in the United States, no policy distinction is implied when referring to either.

2. Of course, the interpretation of extensive varies considerably across countries and over time.

3. European Commission: Eurostat, Statistics Explained: Asylum Statistics, extracted May 21, 2015. http://ec.europa.eu/eurostat/statistics-explained/index.php/Asylum_statistics (accessed January 10, 2016).

4. Changes to the judicial asylum docket have frequently been bundled together with other measures designed to accelerate refugee determination procedures in an attempt to separate genuine claimants from spurious ones - assuming other measures have not already prevented potential refugees from arriving on the state's territory in the first place.

5. I would like to thank one of my anonymous reviewers for this phrasing.

6. The article draws from interviews with two former Constitutional Court judges, a number of key refugee lawyers, nongovernmental organization (NGO) representatives, bureaucrats at the Bundesamt für Migration und Flüchtlinge (Federal Office for Migration and Refugees; BAMF), and judges at lower and upper administrative courts. I also observed hearings at the BAMF and in an upper administrative court.

7. Since legislative changes in 2001, the LAC may only allow an appeal to go forward if (1) it is of a fundamental nature or (2) it diverges from the jurisprudence of the upper courts (VwGO para. 124a (1)). In rare cases, LACs may allow a leapfrog appeal (Sprungrevision, VwGO para. 134) to the FAC if both parties agree. Note that no such leapfrog appeal is allowed for asylum cases. Claimants whose request for an appeal was denied by the LAC could still request an appeal directly from the UAC, but this option was eliminated in 1992 (for asylum cases) and in 1996 (for other cases).

8. Since 2001, the appeal can also be allowed to go forward if the claimant can demonstrate (1) that there are serious doubts as to the overall correctness of the LAC's decision, (2) that there are particularly challenging legal or factual issues at stake, or (3) that a procedural error was committed that was critical to the decision (VwGO para. 124).

9. If the UAC declines the request for leave, the LAC's decision stands (VwGO para. 124a (5)); however, during the evaluation of the (leave to) appeal, all consequences arising from the decision are suspended. If the UAC denies the request, the claimant may still request leave from the FAC directly (also called Nichtzulassungsbeschwerde) (VwGO para. 133). A claimant may still choose to file a constitutional complaint.

10. Some asylum cases are the notable exceptions and will be discussed shortly.

11. This is well chronicled in UNHCR's annual Asylum Trends publication. See http://www.unher. org/551128679.html (accessed January 10, 2016).

12. BT-Drs. are the official documents published by the German Parliament.

13. The percentage of asylum removals of all deportations jumped from 24 percent in 1989 to 77 percent in 1993, which equaled just under 5 percent of all asylum applications in the late 1980s and 15 to 20 percent in the mid-and late 1990s (Ellermann 2009).

14. In its last year of operation, the success rate was 2.3 percent (BT-Drs. $8 / 448,5$ ).

15. Before the Bavarian lower administrative court alone, processing times changed from 26.6 months in 1977 to 43 months in 1979 (BT-Drs. 8/4279, 3).

16. The commissioner's office was abolished as part of immigration reforms in 2005. Interview with Commissioner, September 9, 2002.

17. Regular rejections are designated unfounded and can be appealed further, with somewhat more generous timelines (two weeks for filing an appeal, a month to submit reasons). Asylum law also distinguishes applications deemed inadmissible (i.e., those received from refugees who have 
traveled through safe countries) from cases deemed manifestly unfounded (e.g., applicants from "safe" countries of origin and airport cases).

18. This option continued to exist for regular asylum cases, but their numbers dropped drastically. In 1986 , for instance, there were only 331 such requests; in 2003 , there were only 261 . See German Federal Statistical Office https://www.destatis.de/DE/Publikationen/Thematisch/ Rechtspflege/GerichtePersonal/Verwaltungsgerichte.html (accessed, January 10, 2016). Some data used to be available on the court's website. However, it has not always differentiated policy areas, and at times when it has, asylum and other alien law cases were listed together. Some of the older data were obtained directly from the court. More recently, the court has begun to publish success data for asylum cases. Of the cases filed by refugee claimants, 3.2 percent were successful (i.e., the court ruled in favor of the applicant) in 2014, compared to 26 percent in 2008.

19. Appeal grounds were defined more narrowly than in general administrative law; two grounds available in administrative law were removed entirely for asylum cases.

20. The criteria here accord to the current law. Though they were subsequently fine tuned a number of times, for our purposes the basic principles have remained the same. This procedure has been regulated in Asylgesetz (Asylum Code, AsylG) paragraph 78 since 2008.

21. Interview with LAC judge, August 29, 2002. Initially, manifestly unfounded decisions made by a single judge could still be appealed. This was subsequently changed.

22. Figures here are for appeals (Berufungen) heard only, ignoring other types of motions (especially Beschwerden). Bavaria is used as an example for the state level throughout. Data are available either in hardcopy (Statistisches Jahrbuch für Bayern, various years) or electronically at https://www.statistik.bayern.de/veroeffentlichungen/index.php?cat=c8_Bildung-Rechtspflege.html (accessed January 10, 2016). Bavaria housed the only administrative court in Germany that processed asylum claims prior to 1989 and has the most comprehensive statistics available of all the German states. Some other states did not list asylum cases separately for many years. Bavaria receives the second largest number of refugees of all the German states. Data on administrative courts in other states available through the Federal Statistical Office are not broken down by area of law.

23. Processing times at the initial bureaucratic stage were down to six months in late 1979 but increased again afterward. Court proceedings before the LAC alone took as long as thirtyseven months in Bavaria (which handled all the old cases) and as little as ten to fourteen months in other German states in 1984 (BT-Drs. 10/3346).

24. Asylum applications submitted in industrialized countries declined slightly between 1981 and 1983 (UNHCR Population and Geographic Data Section 2001). Germany's share fell disproportionately as applications from Turkey, which had previously spiked to more than half of all claims due to a military coup in 1980, dropped off drastically. In 1983, Germany saw a new low with 19,737 applications (see Figure 1).

25. Administrative reforms in 1993 also eliminated the power of LACs to allow an appeal to proceed directly to the UAC with its judgment. This option had still allowed a certain number of cases to reach the next appeal level, ranging from a low of 1.2 percent (in Bavaria) in 1983 to a high of 20 percent in 1992 (Statistisches Jahrbuch für Bayern, various years).

26. The support of the opposition was required because a constitutional amendment requires a two-thirds majority in both Houses of the German Parliament.

27. Data for the Bavarian upper administrative court show that the share of asylum appeals (Revisionen) of all cases heard rose to 26.4 percent in 1993 and further increased to 44 percent by 1999. In 2004 it had dropped again to 13.6 percent, only to rise back up to 22.47 percent in 2014. In absolute numbers, however, asylum proceedings before the Bavarian upper administrative court have declined sharply since the late 1990s, although they have increased again slightly since 2008 (Statistisches Jahrbuch für Bayern, various years).

28. Asylum cases constituted roughly 50 percent of the overall caseload of the lower administrative courts (in Bavaria) in 1992. By 1995, the share of asylum cases rose to 66 percent. It then declined noticeably in 2001 to 39 percent and has continued to fall since then to about 30 percent of all proceedings today, compared to the national average of 24 percent, according to federal statistics. In absolute numbers, asylum proceedings before the lower administrative courts (in Bavaria) began to steadily decline from a peak of just over 20,000 cases in 1994 to a low of only 1,888 in 2009. In 2014, they were back up to 6,683 cases (Statistisches Jahrbuch für Bayern, various years).

29. Of the roughly 135,000 cases decided by the Federal Office in 1999 , around 60 percent $(80,000)$ were rejected, and of those roughly 30 percent were deemed manifestly unfounded (Zuwanderung gestalten 2001). 
30. Reform efforts focused on limiting access to the upper administrative courts because access to the Federal Administrative Court had been limited for quite some time, as mentioned earlier.

31. Note that there is no right to free legal aid at the bureaucratic determination hearing and that legal aid for court proceedings is subject to a means and merits-of-the-claim test.

32. For example, in the United Kingdom a 2003 amendment to the country's refugee legislation (that was later withdrawn) proposed ending judicial review to the higher courts for asylum cases (Watts 2004). In Australia the High Court rejected a 2001 piece of legislation that would have restricted its review of asylum matters to only exceptional cases (Plaintiff S157/2002 v Commonwealth of Australia 2003).

33. The right to file a constitutional complaint is regulated in GG article 93(4)a (and also in BverfGG paragraph 90(1)).

34. Each judge employs four clerks.

35. Cases submitted for review or case submissions here means leave applications in the North American context.

36. Due to a substantial backlog, the number of cases in Figure 6 shown as rejected includes cases not just from the year in question (as one might assume) but held over from previous years as well.

37. The one-in-four calculation is based on data from 2003.

38. No formal reasons needed to be given for the dismissal, although rules stipulated the appellant be informed in some way of the basis for the dismissal, which resulted in the Court writing to the respective claimants.

39. These changes were constitutionally challenged - without success.

40. Currently, the Court can charge up to 2,600 Euros for abusive claims. From 1986 to 1993, the Court could also charge a nonacceptance fee. See BverfGG para. 34.

41. Interview with Federal Constitutional Court Judge A on September 17, 2002 and with Federal Constitutional Court Judge B on September 18, 2002.

42. Cases brought before the Court include not only refugee status determination cases but also stays of deportation orders and requests to be admitted to the country. I have excluded other orders (e.g., stay of removal orders) (Einstweilige Anordnungen) from the graph, as it is difficult to ascertain how many cases in this category deal with asylum every year. More recently, the Court has begun to list asylum cases separately for this category. Unfortunately, no separate asylum data prior to 1988 are available.

43. Interview with Federal Constitutional Court Judge B on September 18, 2002. Unfortunately, there are no separate statistics for these cases.

44. Estimate by Federal Constitutional Court Judge A, interviewed on September 17, 2002.

45. Interview with Federal Constitutional Court Judge A on September 17, 2002 and with Federal Constitutional Court Judge B on September 18, 2002.

46. Note that this does not apply to those who are still outside the European Union's borders. Moreover, such assistance is only free for the appeals procedures and only if the appeal is considered to have a "reasonable chance of success" (art. 23). A new version of the directive just came into force in July 2015 (2013/32/EU). Some provisions have to be transposed by 2018 . Note that the Geneva Convention only states that refugees are to be granted free access to the courts in article 16.

47. Interview with UAC judge, August 19, 2002.

Dagmar SoEnNeCKen is an Associate Professor in the School of Public Policy and Administration and in the Department of Social Science (Law \& Society Program) at York University in Toronto, Canada.

\section{REFERENCES}

Blankenburg, Erhard. 2002. "Mobilization of the German Federal Constitutional Court." In Constitutional Courts in Comparison: the U.S. Supreme Court and the German Federal Constitutional Court, edited by R. Rogowski and T. Gawron. New York: Berghahn.

Bosswick, Wolfgang. 2000. "Development of Asylum Policy in Germany," Journal of Refugee Studies 13: 43-60. 


\section{SOENNECKEN The Paradox of Docket Control}

Boswell, Christina. 2003. "Burden-Sharing in the European Union: Lessons from the German and UK Experience," Journal of Refugee Studies 16: 316-35.

---. 2009. The Political Uses of Expert Knowledge: Immigration Policy and Social Research. Cambridge: Cambridge Univ. Press.

Bundesamt für Flüchtlinge and Migration. 2015. Asylgeschäftsstatistik [Asylum Statistics]. http:// www.bamf.de/DE/Infothek/Statistiken/Asylzahlen/asylzahlen-node.html (accessed June 6, 2016).

Bundesverfassungsgericht. 2014. Jahresstatistik 2014. [Annual Statistics 2014]. Karlsruhe, Germany: Bundesverfassungsgericht. http://www.bundesverfassungsgericht.de/DE/Verfahren/Jahresstatistiken/2014/statistik_2014_node.html (accessed June 6, 2016).

Burkiczak, Christian, Franz-Wilhelm Dollinger, and Frank Schorkopf (eds.). 2015. Bundesverfassungsgerichtsgesetz (Heidelberger Kommentar) [Federal Constitutional Court Act (Heidelberg commentary)]. Heidelberg: C.F. Müller.

Coates, Tim, and Caitlin Hayward. 2005. "The Costs of Legal Limbo for Refugees in Canada: A Preliminary Study," Refuge 22: 77-87.

European Council on Refugees and Exiles. 2013. Not There Yet: An NGO Perspective on Challenges to a Fair and Effective Common European Asylum System. Annual Report 2012/2013. Brussels: European Council on Refugees and Exiles. http://www.asylumineurope.org/annual-report20122013 (accessed June 6, 2016).

Ellermann, Antje. 2009. States against Migrants: Deportation in Germany and the United States. Cambridge: Cambridge Univ. Press.

Entlastung des Bundesverfassungsgerichts. Bericht der vom Bundesminister für Justiz eingesetzten Kommisssion [Lightening the Load of the Federal Constitutional Court. Report of the Commission instituted by the Federal Minister of Justice]. 1998. Bonn: Bundesministerium der Justiz.

Epp, Charles R. 1996. "Do Bills of Rights Matter? The Canadian Charter of Rights and Freedoms," American Journal of Political Science 90: 765-79.

---. 1998. The Rights Revolution: Lawyers, Activists, and Supreme Courts in Comparative Perspective. Chicago: Univ. of Chicago Press.

Feeley, Malcolm M., and Edward L. Rubin. 1998. Judicial Policy Making and the Modern State: How the Courts Reformed America's Prisons. Cambridge: Cambridge Univ. Press.

Frowein, Jochen, and Andreas Zimmermann. 1996. "Die Asylrechtsreform des Jahres 1993 und das Bundesverfassungsgericht" [The Asylum Law Reform of the Year 1993 and the Federal Constitutional Court], Juristenzeitung 16: 753-64.

Fullerton, Maryellen. 1988. "Restricting the Flow of Asylum-Seekers in Belgium, Denmark, the Federal Republic of Germany, and the Netherlands: New Challenges to the Geneva Convention Relating to the Status of Refugees and the European Convention on Human Rights," Virginia Journal of International Law 29: 33-114.

---. 2001. "Failing the Test: Germany Leads Europe in Dismantling Refugee Protection," Texas International Law Journal 36: 231-75.

Gibson, James L., Gregory A. Caldeira, and Vanessa A. Baird. 1998. "On the Legitimacy of National High Courts," American Political Science Review 92: 343-58.

Gould, Jon B., Colleen Sheppard, and Johannes Wheeldon. 2010. "A Refugee from Justice? Disparate Treatment in the Federal Court of Canada," Law \& Policy 32: 454-86.

Green, Simon. 2004. The Politics of Exclusion: Institutions and Immigration Policy in Contemporary Germany. Manchester: Manchester Univ. Press.

Greene, Ian, Carl Baar, Peter McCormick, Martin Thomas, and George Szablowski. 1998. Final Appeal: Decision-Making in Canadian Courts of Appeal. Toronto: J. Lorimer.

Greene, Ian, and Paul Shaffer. 1992. "Leave to Appeal and Leave to Commence Judicial Review in Canada's Refugee Determination System: Is the Process Fair?" International Journal of Refugee Law 4: 71-83.

Guiraudon, Virginie. 2000. "European Integration and Migration Policy: Vertical Policy-making as Venue Shopping," Journal of Common Market Studies 38: 251-71.

Hirschl, Ran. 2004. Towards Juristocracy: The Origins and Consequences of the New Constitutionalism. Cambridge, MA: Harvard Univ. Press.

Ingman, Terence. 2002. The English Legal Process, 9th ed. Oxford: Oxford Univ. Press.

Joppke, Christian. 1998. "Asylum and State Sovereignty: A Comparison of the United States, Germany, and Britain." In Challenge to the Nation-State: Immigration in Western Europe and the United States, edited by C. Joppke. Oxford: Oxford Univ. Press.

---. 1999. Immigration and the Nation-State: The United States, Germany and Great Britain. Oxford: Oxford Univ. Press. 
Karlen, Delmar. 1963. Appellate Courts in the United States and England. New York: NYU Press.

Kaunert, Christian, and Sarah Léonard. 2012. "The Development of the EU Asylum Policy: Venue-Shopping in Perspective," Journal of European Public Policy 19: 1396-1413.

Kirchhof, Paul. 2013. "Staatliche Souveränität als Bedingung des Asylrechts" [State Sovereignty as a Condition of the Right to Asylum]. In Grenzüberschreitendes Rech-Crossing Frontiers: Festschrift für Kay Hailbronner [Border-crossing law_crossing frontiers: Festschrift for Kay Hailbronner], edited by G. Jochum, W. Fritzenmeyer, and M. Kau. Heidelberg: C. F. Müller.

Kneebone, Susan (ed.). 2009. Refugees, Asylum Seekers and the Rule of Law: Comparative Perspectives. Cambridge: Cambridge Univ. Press.

Kommers, Donald. 1997. The Constitutional Jurisprudence of the Federal Republic of Germany, 2nd rev. and exp. ed. Durham, NC: Duke Univ. Press.

Koser, Khalid. 2000. "Germany: Protection for Refugees or Protection from Refugees?” In Kosovo's Refugees in the European Union, edited by J. van Selm. London: Pinter.

Kranenpohl, Uwe. 2010. Hinter dem Schleier des Beratunggeheimnisses: Der Willensbildungs- und Endscheidungsprozess des Bundesverfassungsgerichts [Behind the veil of the confidential consultations: The decision-making process of the Federal Constitutional Court]. Wiesbaden: VS Verlag für Sozialwissenschaften.

Lamprecht, Rolf. 1996. Zur Demontage des Bundesverfassungsgerichts [The dismantling of the Federal Constitutional Court]. Baden-Baden: Nomos.

Lavenex, Sandra. 2001. The Europeanisation of Refugee Policies: Between Human Rights and Internal Security. Aldershot, UK: Ashgate.

Miller, Banks, Linda Camp Keith, and Jennifer S. Holmes. 2014. Immigration Judges and U.S. Asylum Policy. Philadelphia: Univ. of Pennsylvania Press.

Münch, Ursula. 1992. Asylpolitik in der Bundesrepublik Deutschland: Entwicklungen und Alternativen [Asylum politics in the Federal Republic of Germany: Developments and alternatives]. Opladen, Germany: Leske und Budrich.

Pagenkopf, Martin. 1982. "Die Neuregelung des Asylverfahrensrechts," [The new rules of the Asylum Procedure Code] Neue Zeitschrift für Verwaltungsrecht 11: 590-96.

Pierson, Paul. 2004. Politics in Time: History, Institutions, and Social Analysis. Princeton, NJ: Princeton Univ. Press.

Rivers, Julian. 1994. "Stemming the Flood of Constitutional Complaints in Germany," Public Law 4: 553-63.

Rogowski, Ralf, and Thomas Gawron (eds.). 2002. Constitutional Courts in Comparison: the U.S. Supreme Court and the German Federal Constitutional Court. New York: Berghahn.

Rosenberg, Gerald N. 2008. The Hollow Hope: Can Courts Generate Social Change? 2nd ed. Chicago: Univ. of Chicago Press.

Schenk, Karlheinz. 2002. "Die Entwicklung des Asylrechts in der 50-jährigen Rechtsprechung des BVerfG" [The Development of the Right to Asylum over 50 Years in the Jurisprudence of the FCC], Neue Zeitschrift für Verwaltungsrecht 7: 803-10.

Schuster, Lisa. 2003. The Use and Abuse of Political Asylum in Britain and Germany. London: Frank Cass.

Segal, Jeffrey A. 1997. "Separation-of-Powers Games in the Positive Theory of Congress and Courts," American Political Science Review 91: 28-44.

Seibert, Max-Jürgen. 1999. "Das Verfahren auf Zulassung der Berufung_Erfahrungen mit der 6. VwGO-Novelle" [The Leave to Appeal Procedures at the Second Instance-Experiences with the 6th Reform of the Administrative Court Act.], Neue Zeitschrift für Verwaltungsrecht 18: 113-20.

Singer, Michael. 1982. "The Constitutional Court of the German Federal Republic: Jurisdiction over Individual Complaints," International and Comparative Law Quarterly 31: 331-56.

Sodan, Helge, and Jan Ziekow (eds.). 2002. Nomos-Kommentar zur Verwaltungsgerichtsordnung [Nomos-commentary of the Administrative Court Act], 4th ed. Baden-Baden: Nomos.

Statistisches Jahrbuch für Bayern [Statistical yearbook of Bavaria]. Various years. München: Landesamt für Statistik und Datenverarbeitung (online from 2004 onwards). https://www.statistik. bayern.de/veroeffentlichungen/advanced_search_result.php?keywords $=$ B6300C (accessed on June 6, 2016).

UNHCR. 2015. Asylum Trends 2014: Levels and Trends in Industrialized Countries. Geneva: UNHCR.

UNHCR Population and Geographic Data Section. 2001. Asylum Applications in Industrialized Countries: 1980-1999. Geneva: UNHCR. http://www.unhcr.org/en-us/statistics/unhcrstats/3c3eb40f4/ asylum-applications-industrializedcountries-1980-1999-nov-2001.html (accessed June 6, 2016). 
Von Sternsdorff, Hans-Wolfgang, and Wolfgang Bayer. 1982. "Massenware, bei der nichts herauskomm" [Mass Products with No Results], Der Spiegel. April 26. http://www.spiegel.de/ spiegel/print/d-14346521.html (accessed on June 6, 2016).

Watts, Nicolas. 2004. "Reprieve for Asylum Appeals," The Guardian, March 16. http://www.theguardian.com/politics/2004/mar/16/immigration.constitution (accessed June 2, 2016).

Wieland, Joachim. 2002. "The Role of Legal Assistants at the German Federal Constitutional Court." In Constitutional Courts in Comparison: The U.S. Supreme Court and the German Federal Constitutional Court, edited by R. Rogowski and T. Gawron. New York: Berghahn.

Wolken, Simone. 1988. Das Grundrecht auf Asyl als Gegenstand der Innen- und Rechtspolitik in der Bundesrepublik Deutschland [The fundamental right to asylum as a subject for politics and law in the Federal Republic of Germany]. Frankfurt am Main: Peter Lang.

Zuwanderung gestalten - Integration födern (Bericht der Unabhängige Kommission "Zuwanderung"). [Shaping Immigration-Promoting Integration (Report of the Independent Commission "Immigration")]. 2001. Berlin: Bundesministerium des Innern.

\section{CASES CITED}

BVerfGE $65,76$.

BVerfGE $67,43$.

BVerfGE 56, 216-44.

BVerfGE 94, 49; 94, 115; 96, 166.

BVerfG, 18.07.2012-1 BvL 10/10, 1 BvL 2/11.

Plaintiff S157/2002 v Commonwealth of Australia [2003] HCA 2, February 4, 2003.

\section{GOVERNMENT DOCUMENTS CITED}

BT-Drs. 8/448.

BT-Drs. 8/4279.

BT-Drs. 8/2946.

BT-Drs. 9/875.

BT-Drs. 10/1255.

BT-Drs. 10/3346.

BT-Drs. 12/3628.

BT-Drs. 14/6393.

BT-Drs. 18/2471.

BT-Drs. 18/3850. 